\title{
ACADEMIC SUPPORT FOR FIRST-YEAR SOCIAL WORK STUDENTS IN SOUTH AFRICA
}

\section{Kathleen Collins, Adrian van Breda}

\section{CONTEXT FOR FIRST-YEAR SUPPORT}

Students in their first year face the great challenge of transition from school to university, where independent and self-directed learning is called for. Students must navigate multifaceted life adaptations - physical ones such as moving away from home, and psychological ones such as moving into young adulthood, from the familiarity of the homogeneous school environment to the heterogeneous culture of the university, often from rural to urban, to a different language, to mixing with diverse race groups. Moving from the control, protection and predictability of school life, learners are free for the first time to test their autonomy and experiment with choices. Equally, the challenge of providing the best teaching and learning to this group rests with the educators in first year.

Particularly in the realities of the South African context, first year has to be a platform for developing students' academic potential in new modes of learning, and consequently carries unique opportunities and attendant responsibility to the individuals involved and to the country (Scott, 2008:9).

The approach to learning at school often makes it very difficult for learners to adapt to the "deep learning" required at university (Blunt, 2008). In social work, there are additional requirements of applying theory from their lectures to practice in the community, and of internalising the values and ethics associated with a profession. These requirements are operationalised by Exit-Level Outcomes (ELOs). The ELOs for Social Work I, developed according to SAQA standards, are explicit and are applied in an outcomes-based approach by Social Work departments at South African universities (Bozalek, 2009).

There is a history of a high attrition rate among first-year social work students, as in all firstyear courses at tertiary institutions in South Africa (Council on Higher Education, 2009; Scott, Yeld \& Hendry, 2007; Scott, 2008). Throughput at this stage is very poor, hence extensive academic support both at the wider university level and at the teaching programme level has been introduced to assist first-year adaptation. Extended programmes and foundation courses have been established. Much attention has been devoted worldwide to innovative teaching and learning methods, and in particular to assessment (Boud, 1990, Butcher, Davies \& Highton, 2006; Davies, Welch \& Hargis, 2008; Ederer, Schuller \& Williams, 2008; Gibbs, 2006). These methods and accompanying philosophies have been formally adopted in university policies on teaching and learning, and are already in practice in South Africa (Wolpe, Badat \& Barends, 1993; Scott et al., 2007).

A conference forum investigating the first-year experience, accompanied by ongoing research and collaboration, was established in 2008 , where many conversations on first-year success

\footnotetext{
1 "Deep learning" is defined as making sense of ideas. It seeks constructivist integration between components of ideas as well as between tasks and new concepts. In deep learning knowledge can be related to one's own position, whereas "surface learning" involves only reproduction of the work of others. Surface learning leads to boredom with and avoidance of the subject, while deep learning promotes involvement and new ideas.
} 
were opened $\left(1^{\text {st }}\right.$ Southern African Conference on the First-Year Experience, 2008). Most academics observed a continued trend of poor performance of students, while recognising the obstacles to learning. These obstacles can be cognitive (Butcher et al., 2006; Egan, 1997; Grosling, Thomas \& Heagny, 2008) as well as familial and social (Jones, Coetzee, Bailey \& Wickham, 2008; Schenck, 2008, 2009; Tshiwula, 2007). In 2007 the establishment of social work as a scarce skill by the South African Government's Department of Labour led to the implementation of a recruitment and retention strategy by the Department of Social Development, with its accompanying financial assistance for student training. This national focus foregrounds the importance of gaining knowledge in educational input and learner response in social work training.

The aspects relevant to the adjustment process in first year are: selection, admission, philosophies of education, teaching methods, assessment methods, university policies and procedures, infrastructural and human resources, indigenisation of teaching and learning, and social and familial environments. All of these aspects have an impact on the deep learning that we set as a standard for our students. In order for deep learning to take place, effort from both educator and learner is required. A learning partnership with clear expectations and roles must be defined. Leadership in South African social work education have acknowledged their willingness to explore these expectations and roles at the strategic planning meeting of the Association of South African Social Work Educational Institutions (ASASWEI) in September 2008. Concerns were tabled and a decision was taken to conduct a research project on the ways in which more effective assistance can be provided to learners in the social work programme (Beytell, 2008). The knowledge obtained from the research would be shared amongst the different institutions and could give impetus to further action and evaluation.

The following review presents the principles of expectations and roles, with particular reference to the situation of South African students of social work. Under every subheading there is a concluding section describing the implications for social work education in the first year. A newly designed collaborative research project intends to address the implications in case studies carried out in social work departments throughout the country. The project addresses the ways in which deep learning can be developed as a culture of learning for firstyear students. The research question is: "In what ways are educators of social work developing deep learning in first-year students?" The aim is: to identify and describe practices promoting deep learning applied by educators in the first-year level of the social work programme (Collins, Pretorius, Smith \& Van Breda, 2009).

\section{ADULT EDUCATION AND EXPERIENTIAL LEARNING}

\section{Adult education}

Adult education (andragogy) is an approach to learning that has enjoyed widespread attention and interest over many years (Knowles, 1988). Adult education recognises that adults enter a learning programme with life experiences, knowledge, skills and wisdom (Moxley, NajorDurack \& Dumbrigue, 2000). From a strengths perspective (Saleebey, 2008) or assets-based approach (Kretzmann \& McKnight, 1993), we can view such learning as assets - they are strengths and capabilities that adult learners bring with them (Moxley et al., 2000). Adult learning, therefore, begins with an assumption that learners are not blank slates, but rather competent and experienced people. Consequently, learning starts with what they already know and builds towards what they do not yet know. 
Freire (1993) has contrasted two approaches to learning as "banking education" and "problemposing education". In banking education the all-knowing teacher (the banker) deposits information into the empty heads of passive students. The more information the teacher is able to bank, the better teacher she is. The more passively the students allow themselves to be filled, the better students they are. By contrast, the problem-posing approach involves an educator who presents learners with problems and facilitates their engagement with those problems towards finding a solution. Here, learners are active and critically engaged with the learning materials and processes. Through this kind of engagement, Freire argues that they not only become educated, but also conscientised, empowered and transformed.

Moxley et al. (2000) indicate that adult education is particularly concerned to understand why adult learners want to learn - what is their motivation and incentive for learning. "The educator examines how education now fits into professional development or work advancement of the adult learner. The educator must understand the learner's motivation or reasons to pursue higher education in relationship to where they want to go with their careers or their lives" (Moxley et al., 2000:337). Adult learners do not sign up for courses for no reason. Unlike children who are required to attend school, irrespective of their own interests, adult learners typically seek out learning opportunities that will advance their own interests.

Moxley et al. (2000) link this principle to the empowerment and strengths perspectives' commitment to facilitating human goal achievement. It is an exercise in "mastery" in which we facilitate people's achievement of the vision and dreams that they have for themselves. When an adult enters university with the dream of becoming a social worker, an educator's primary task is to facilitate that person's journey towards realising the dream.

Knowles (cited in Askeland, 2003:355) has identified four key principles of adult learning. Adults learn best when:

- They are "actively involved in their own learning process";

- We use questions that are of concern to them as the basis for the learning experiences;

- "New material can be related to their own experiences";

- "Newly gained knowledge and skills can immediately be tried out for use".

\section{Experiential learning}

Experiential learning is closely allied with adult education (Sutherland, 1998). Experiential learning argues that the best learning is rooted in real experiences, and we all have real experiences, even our students (Askeland, 2003). Knowledge, while important, always follows experience. And central to experiential learning is the capacity to reflect critically on and apply learning to the real world. Hope and Timmel (1984) describe the experiential learning cycle, which involves four phases:

- Direct experience - Here we create an immediate experience for learners that serves as a foundation for learning to take place. Typically this is an experience in the classroom, although one can also draw on the life experiences of learners from outside.

- Reflection on the experience - Here we take a small step back from the experience and reflect on what that experience says to us - what took place and how we experienced it. It is a personal response to the experience that facilitates introspection, reflexivity and insight.

- Generalisation about the experience - Here we take a few more steps back from the experience and our personal reflection on the experience. We explore what we can learn 
from this experience and begin to link this particular experience to a broader range of experiences and situations. It is here that theory is introduced - to help interpret the experience at a higher level.

- Application - Finally, we look at how to apply the learning that has been achieved, exploring what this means for the way we do things. The learning does not remain at the abstract level of phase three, but progresses into the world as a new way of living. Since this is a cycle of learning, the application of learning becomes a new experience, leading into a new cycle of reflection, generalisation and application.

Askeland (2003:356) indicates that this cycle is a means to promote:

- "working through and reflecting on personal experiences;

- becoming conscious of tacit knowledge;

- integrating practice and theory;

- becoming aware of challenges and areas for developing new competence."

\section{Implications for social work education}

In our experience, however, the ideals of adult and experiential learning are not applicable to many of our social work students. They study social work perhaps because other apparently more demanding programmes do not accept them, or because the Department of Social Development bursary provides them with the only course they can afford to study. Some of our students have no interest in becoming social workers. The majority of them are first-generation tertiary students, with no role models for learning or professional practice. Furthermore, while students are technically "adults", many do not behave with the maturity of adults entering postgraduate studies or less well educated adults who later in life decide to pursue further education. We may wonder what life experiences these youngsters bring to our classes that we can draw on.

Given these concerns, what are the implications of adult and experiential learning for the education of first-year social work students? We suggest there are three implications.

- Start with what they know - A clear and important principle in the case of both philosophies of education is to start with what our students know and have experienced. Curiously, this is one of the principles of good social work practice, particularly the assetsbased and strengths perspective approaches to social work. Our students do come to university with life experiences and these experiences could serve as the foundation for learning (Askeland, 2003). For example, many of our students have lived in conditions of poverty and deprivation, and many have experienced a wide range of trauma and hardship (Schenk, 2008; Tshiwula, 2007). When teaching about contemporary social problems, we could draw on these life experiences, which when shared will have substantial meaning and relevance for learners. When we later teach welfare approaches to these problems, learners will be able to link residual, developmental and other welfare approaches to their own life experiences.

- Develop the future selves of students - Rather than lament the lack of interest of many students in becoming social workers, we could actively work to develop the sense of professional identity of our students. The theory of possible or future selves (Markus \& Nurius, 1986) argues that we are motivated not only by present and past behaviours and experiences, but also (and in large measure) by our vision of our future. Markus and Nurius have shown that a clear picture of who I dream of being in the future (the future self) 
actively motivates current behaviour. Given that adult learning emphasises the importance of motivation to learn, developing social work students' future selves could contribute significantly towards increased motivation to learn.

- Learn by doing - Both adult learning and experiential learning, as well as action learning, emphasise the importance of "learning through doing". With the increasing size of classes, active learning has become increasingly difficult. However, it may be possible to design creative learning tasks, which students can perform either in class or as an assignment, that would stimulate learning through doing. In theory, this form of learning will endure beyond the next test or exam.

\section{CRITICAL REFLECTION AND REFLEXIVITY}

\section{Critical reflection}

The critical reflection approach to education argues that we educate to change the world, not merely to know about the world (Brookfield, 1995). This means that we need to be able to recognise the dynamics by which the world operates, dynamics of hegemony, power, oppression and injustice. The crux of critical reflection is the hunt for assumptions, which are "the taken-for-granted beliefs about the world and our place within it that seem so obvious to us as not to need stating explicitly" (Brookfield, 1995:2). Critical reflection is a process of digging under what is obvious, what is taken for granted.

Critical reflection is not the same as knowledge. Knowledge entails learning predetermined facts. These facts were presumably developed by a particular person in a particular context and time. Students who learn these facts may be unable to transfer them to other contexts or to use them flexibly and intelligently. Critical reflection, on the other hand, is a process, a way of looking at the world. Once that process has been mastered, it can be applied in almost any situation. Critically reflective social workers would have a competence that can be of value with any social issue - HIV prevention, domestic violence, schizophrenia and poverty alleviation. This competence is essential to effective social work practice in South Africa (Clare, 2007; Sacco, 2004), particularly when faced with ethical dilemmas (Gray \& Gibbons, 2007). These two approaches can be contrasted as knowledge transfer and knowledge transformation (Askeland \& Bradley, 2006) - the former involves uncritically pasting knowledge from one context or social issue into another, while the latter involves taking on the essential elements of knowledge, making them one's own and then thoughtfully applying them in new ways in new contexts or to different social issues.

Brookfield (1995:28) argues that "the best way to unearth these assumptions [of power and hegemony] is to look at what we do from as many unfamiliar angles as possible." In this way we learn to step outside of our own assumptions and paradigms and to view the world through different lenses. Writing for educators - to help us become critically reflective - Brookfield (1995:28) suggests there are four critically reflective lenses, viz. "(1) our autobiographies as teachers and learners, (2) our students' eyes, (3) our colleagues' experiences, and (4) theoretical literature".

For our students, we could suggest that students should engage with their own previous life experiences, with the experiences and perceptions of their social work classmates, with the experiences and perceptions of their non-social work friends and family members, and with theory. These engagements could help students recognise the taken-for-granted assumptions 
that lie beneath many of the social problems we encounter in social work. Such engagement could be facilitated in classroom settings as well as in assignments and field exercises.

\section{Reflexivity}

Reflexivity, a term related to reflectivity, can be thought of as a form of reflection that recognises the role that we ourselves play in a situation (Fook, 2002). The capacity to reflect on the self-in-action is a crucial competence, particularly when students begin their internships. We are deeply interested in their internal processes, as these point to their professional growth and their personal development, domains that we regard as central to good social work practice. Reflexivity is, of course, a highly personal/personalised process. While critical reflection tends to be outward looking (except as it may involve challenging our own assumptions), reflexivity is inward looking (except inasmuch as it involves the self in relation to the world outside). Reflexivity inevitably and ideally leads to a sense of vulnerability. Students who feel scrutinised and insecure are unlikely to be willing to become vulnerable, particularly when their teachers are not vulnerable. Consequently, the development of reflexivity in learners requires a correspondingly large amount of reflexivity on the part of educators.

Reflexivity thus shapes an approach to education that is authentic, transparent, honest, vulnerable and open. Educators are no longer just professors and doctors, but human beings with flaws, who make mistakes, who are willing to use their own vulnerabilities to facilitate their own learning and thereby the learning of others. When educators take this approach, they help to create a culture of reflection that students will assimilate (Sacco, 2004).

\section{Implications for social work education}

We outline three implications of critical reflection and reflexivity for the education of first-year social work students:

- Opinions are important - Traditionally, we have not been much interested in the opinions and views of junior students. We have been told (and may have told our students), "I am not interested in your opinion. I am only interested in what has been published in the literature." This approach to education promotes the banking approach and extinguishes critical reflection. Even at first-year level, we should begin the process of developing the capacity for critical reflection, through setting assignments (or parts of an assignment) that require students to provide their opinion on something and to be critical of their own opinions. This could also be done in triads or small groups in which students reflect critically on each others' work.

- Learning in partnership - There is a social dimension to learning that is often underutilised in traditional educational settings (Parker, 2007). Twenty-first century students are strongly relational and seek to learn with and through others. It is in such learning partnerships that critical reflection can be developed, as students' unacknowledged assumptions knock up against the unacknowledged assumptions of their peers. In so doing, both have the opportunity to reflect critically on their assumptions. Students can be paired off into learning partnerships and given a range of tasks to perform together (Boud \& Knights, 1996; Saltiel, 1998). These experiences can be journalised and reflected upon to facilitate critical reflection.

- Learn with the learners - We learn most effectively through copying those who teach us. Many of us will recognise that our own approach to education has been significantly shaped by the way we were taught, for better or for worse. If we apply this to the next generation, it suggests that our students will practise social work in the way that we have taught them 
(East \& Chambers, 2007). This calls for a high level of critical reflection on our own approaches to teaching. The development of reflexivity in other requires us to be selfreflexive. This implies that we need to be open to acknowledging our mistakes, willing to share our vulnerabilities, ready to receive critical feedback from students, and honest enough to be genuine and authentic human beings.

\section{TECHNOLOGY-ASSISTED LEARNING (TAL)}

Twenty-first century students have grown in their use of technology far beyond most academics. The persistent and exclusive use of traditional approaches to education may result in our missing an approach to learning that is highly consonant with the learning style of most of our younger students. Students are able to locate information rapidly online. They interact with others as much online as face-to-face, through My Space, Facebook and Mixit. They intuitively pick up and master new technologies without having to read the manual or attend a course. These students are highly receptive to technology-assisted learning (TAL), which integrates information technology into education.

Social work has, however, been reluctant to utilise TAL. Perhaps this is in part a result of our own anxiety about computers. Perhaps it is because of our commitment to an integrated learning experience with competency-based outcomes. Perhaps it is because we are intent on developing interpersonal skills that require face-to-face learning opportunities. When TAL is used, there is a tendency to use it as a repository of information - a collection of literature, PowerPoint slides and handouts. There is little use of actual interactive TAL. The University of the Western Cape's Social Work Department is probably unique in South Africa in having developed several online courses that promote deep learning (Bozalek, Rohleder, Carolissen, Leibowitz, Nicholls \& Swartz, 2007; Bozalek \& Matthews, 2009; Rohleder et al., 2008).

Blended learning approaches (blending traditional classroom teaching with other approaches to learning, including TAL) have been used successfully to develop, for example, practice competencies in child welfare (Bellefeuille, Martin \& Buck, 2005), micro-practice skills (Regan \& Youn, 2008), research competence (Banks \& Faul, 2007), critical reflection in large classes (Auslander, 2002) and academic competencies in social work students (Van Breda \& Nefdt, 2009). These studies suggest that TAL approaches are as effective as face-to-face approaches to teaching. Regan and Youn (2008) detail a range of possibilities for developing applied competencies in students through TAL systems. As technology advances, at an alarmingly rapid pace, the possibilities increase exponentially. They caution, however, that technology should be used thoughtfully, with consideration for the learning outcomes of the educational programme. There is a risk of technology being used as a fad, rather than as one among several tools in an educator's repertoire of teaching methods.

Reeves and Reeves (2008:47-48) similarly caution that technology should be used thoughtfully, and suggest ten dimensions that need to be considered before deciding to use TAL: (1) pedagogical philosophy (instructivist or constructivist); (2) learning theory (behavioural or cognitive); (3) goal orientation (sharply focused or general); (4) task orientation (academic or authentic); (5) source of motivation (extrinsic or intrinsic); (6) teacher role (didactic or facilitative); (7) metacognitive support (unsupported or integrated); (8) collaborative learning support (unsupported or integral); (9) cultural sensitivity (insensitive or respectful); and (10) structural flexibility (fixed or open). 


\section{Implications for social work education}

We present one implication of TAL for the education of first-year social work students:

- Creativity in education - TAL is by no means the solution for all our concerns, but neither is it the enemy of holistic social work education. The challenges that social work educators face with first-year students calls for a high level of creativity and innovation in educational approaches. The incorporation of TAL into the learning processes is one form of creativity that matches well with the increasing computer literacy of new social work students. TAL is, of course, challenging for many educators. Good technology and instructional design support is thus imperative.

\section{CONCLUSION}

In many ways, social work education is already aligned with the National Qualifications Framework (NQF) and outcomes-based education (OBE) approach, required by the South African Qualification Authority (SAQA) and specified in several documents (SAQA, 2001, 2004). This alignment is because our discipline, in contrast with the purer social sciences (sociology for example), is an applied science. The ELOs for social work operationalise the alignment. We therefore understand that we are training people to practise in the real world, not merely to know information. Nevertheless, the following are three of the central implications of OBE and specific ELOs for the education of first-year social work students:

- Academic competencies - In the first year of study, students should acquire the academic competencies to successfully undertake tertiary level studies. Although our primary mandate is to lay the foundation for social work competence, academic competencies are a crucial prerequisite to throughput of quality students. Basic academic competencies include, among others, to study, to source academic literature, to read intelligently, to write essays, to utilise literature in one's arguments and to think critically (Wichita State University, n.d.). We have seen that simply outsourcing the development of academic competencies to academic support/development departments is ineffective, as students do not transfer their learning from that environment into their social work classes (Van Breda \& Nefdt, 2009). What is required is an approach that integrates the development of academic competencies into the actual social work courses and is scaffolded over the first year in bite sizes and logical steps (e.g. first develop the freedom and skills to write; then the ability to source and summarise literature; then to construct an argument and essay; then to reference sources accurately).

- Professional competencies - The value of OBE's foregrounding of outcomes and competencies is to help educators remain resolute in their focus on the learning of students and what students will be able to do with their learning in the real world. First-year social work programmes are typically introductory - we lay the foundation of knowledge of contemporary social problems, the social development and developmental social welfare perspectives, the history and values of social work and fields of practice. Given the introductory nature of these subjects, it is easy to fixate on information and knowledge, and neglect the applied competence. The focus on applied competencies, as specified in exitlevel outcomes, helps us continually ask the question: "What should our students be able to do with this knowledge?"

- Assessment - Assessments of students need to target more than just knowledge. Knowledge is an important part of the OBE approach - the NQF refers to this as "essential 
embedded knowledge", emphasising that there are certain bodies of knowledge that are essential for learners to master. This knowledge is, however, embedded, meaning that it is part of the foundation of competence, but not the competence itself. For example, it is essential that students know the theory of community development. But this is not sufficient for them to be good social workers. This knowledge, while essential, is part of the bedrock of the competence to actually engage in community development. Thus, assessments need to focus not only on knowledge but also on the application of that knowledge. At first-year level this suggests that students should be able to begin working in their assessments with case studies, examples and simulations.

The project planned in response to the request from ASASWEI in 2008 will undertake research on improved education of our students, incorporating the principles outlined above. The study will be participatory in approach by inviting participants, both educators and learners, to shape the way data are collected and by facilitating a problem-solving process towards producing self-generated recommendations for intervention. The design is predominantly qualitative, but will include a number of quantitative elements. It is cross-sectional and not longitudinal, although it is envisaged that a follow-up study could be conducted after a year to assess the results of implemented interventions to further develop students' deep learning (Collins et al., 2009). The project proposal will be discussed at ASASWEI's annual general meeting in 2009.

\section{REFERENCES}

$1^{\text {st }}$ SOUTHERN AFRICAN CONFERENCE ON THE FIRST-YEAR EXPERIENCE. 2008. Opening conversations on first-year success. University of Stellenbosch, South Africa.

ASKELAND, G.A. 2003. Reality-play: experimental learning in social work training. Social Work Education, 22(4):351-362.

ASKELAND, G.A. \& BRADLEY, G. 2006. Linking critical reflection and qualitative research on an African social work master's programme. International Social Work, 50(5):671-685.

AUSLANDER, G.K. 2002. Using large classes to positive advantage: involving students as research subjects and active learners. Social Work Education, 19(4):375-385.

BANKS, A.C. \& FAUL, A.C. 2007. Reduction of face-to-face contact hours in foundation research courses: impact on students' knowledge gained and course satisfaction. Social Work Education, 26(8): 780-793.

BELLEFEUILLE, G., MARTIN, R.R. \& BUCK, M.P. 2005. From pedagogy to technagogy in social work education: a constructivist approach to instructional design in an online, competency-based child welfare practice course. Child and Youth Care Forum, 34(5):371389.

BEYTELL, A. 2008. Report on ASASWEI meeting. Pretoria, South Africa.

BLUNT, R. 2008. Turning apartheid around. In: GROSLING, G., THOMAS, L. \& HEAGNEY, M. (eds) Improving student retention in higher education: the role of teaching and learning. London: Routledge.

BOUD, D. 1990. Assessment and promotion of academic values. Studies in Higher Education, 15(1):101-111.

BOUD, D. \& KNIGHTS, S. 1996. Course design for reflective practice. In: GOULD, N. \& TAYLOR. I. (eds) Reflective learning for social work. Hants, UK: Arena. 
BOZALEK, V. 2009. Outcomes-based assessment: necessary evil or transformative potential? Social Work/Maatskaplike Werk, 45(1):91-110.

BOZALEK, V. \& MATTHEWS, L. 2009. E-learning: a cross-institution forum for sharing socio-cultural influences on personal and professional identity. International Social Work, $52(2): 222-233$.

BOZALEK, V., ROHLEDER, P., CAROLISSEN, R., LEIBOWITZ, B., NICHOLLS, L. \& SWARTZ, L. 2007. Students learning across differences in a multi-disciplinary virtual learning community. South African Journal of Higher Education, 21(7):812-825.

BROOKFIELD, S.D. 1995. Becoming a critically reflective teacher. San Francisco, CA: Jossey-Bass.

BUTCHER, C., DAVIES, C. \& HIGHTON, M. 2006. Designing Learning: from module to effective teaching. London: Routledge.

COUNCIL ON HIGHER EDUCATION. 2009. [Online] Available: http://www.che.ac.za [Accessed: 29/06/2009]

CLARE, B. 2007. Promoting deep learning: a teaching, learning and assessment endeavour. Social Work Education, 26(5):433-446.

COLLINS, K.J., PRETORIUS, B., SMITH, P. \& VAN BREDA, A.D. 2009. Teaching and learning experiences of first-year social work students in South Africa. Report for the Association of South African Social Work Educational Institutions. Bellville, South Africa.

DAVIES, J., WELCH, C. \& HARGIS, J. 2008. The Bridge Course design: formative assessment and student-centred learning in cross-course classrooms. International Journal for the Scholarship of Teaching and Learning, 2(2):1-17.

EAST, J. \& CHAMBERS, R. 2007. Courage to teach for social work educators. Social Work Education, 26(8):810-826.

EDERER, P., SCHULLER, P. \& WILLIAMS, S. 2008. University systems ranking: citizens and society in the age of knowledge. Brussels: The Lisbon Council.

EGAN, K. 1997. The educated mind: how cognitive tools shape our understanding. Chicago: The University of Chicago Press.

FOOK, J. 2002. Social work: critical theory and practice. London, UK: Sage Publications.

FREIRE, P. 1993. Pedagogy of oppressed. London, UK: Penguin.

GIBBS, G. 2006. How assessment frames student learning. In: BRYAN, C. \& CLEGG, K. (eds) Innovative assessment in higher education. London: Routledge.

GRAY, M. \& GIBBONS, J. 2007. There are no answers, only choices: teaching ethical decision making in social work. Australian Social Work, 60(2):222-238.

GROSLING, G., THOMAS, L. \& HEAGNY, M. (ed) 2008. Improving student retention in higher education: the role of teaching and learning. London: Routledge.

HOPE, A. \& TIMMEL, S. 1984. Training for transformation: a handbook for community workers (vol 1). Gweru, Zimbabwe: Mambo Press. 
JONES, B., COETZEE, G., BAILEY, T. \& WICKHAM, S. 2008. Factors that facilitate success for disadvantaged higher education students. Athlone, RSA: Rural Education Access Programme.

KNOWLES, M.S. 1988. The modern practices of adult education: from pedagogy to andragogy $\left(2^{\text {nd }}\right.$ ed). Englewood Cliff, NJ: Cambridge Book Company.

KRETZMAN, J. \& McKNIGHT, J. 1993. Building communities from the inside out: a path toward finding and mobilizing a community's assets. Evanston, IL: Northwestern University.

MARKUS, H. \& NURIUS, P. 1986. Possible selves. American Psychologist, 41(9):954-969.

MOXLEY, D.P., NAJOR-DURACK, A. \& DUMBRIGUE, C.Y. 2000. Seven strategies for facilitating access of nontraditional students to graduate education in social work. Social Work Education, 19(4):335-348.

PARKER, J. 2007. Developing effective practice learning for tomorrow's social workers. Social Work Education, 26(8):763-779.

REEVES, P.M. \& REEVES, T.C. 2008. Design considerations for online learning in health and social work education. Learning in Health \& Social Care, 7(1):46-58.

REGAN, J.R. \& YOUN, E.J. 2008. Past, present, and future trends in teaching clinical skills through web-based learning environments. Journal of Social Work Education, 44(2):95-115.

ROHLEDER, P., BOZALEK, V., CAROLISSEN, R., LEIBOWITZ, B., NICHOLLS, L. \& SWARTZ, L. 2008. Students' evaluations of the use of e-learning in a collaborative project between two South African universities. Higher Education, 56(1):95-107.

SACCO, T.M. 2004. A competency-based, critically reflective approach to social work field instruction. Social Work Practitioner-Researcher, 16(2):170-180.

SALEEBEY, D. (ed) 2008. The strengths perspective in social work practice $\left(5^{\text {th }}\right.$ ed). Boston, MA: Allyn \& Bacon.

SALTIEL, I.M. 1998. Adult students as partners in formal study. New Directions for Adult \& Continuing Education, 79:13-22.

SAQA. 2001. Criteria and guidelines for assessment of NQF registered unit standards and qualifications. Pretoria, RSA: South African Qualifications Authority.

SAQA. 2004. The National Qualifications Framework: an overview. Pretoria, RSA: South African Qualifications Authority.

SCHENCK, C.J. 2008. Should being a South African make social work training different? Towards giving new meaning to concept "student-centredness". Inaugural lecture. UNISA, Pretoria, South Africa.

SCHENCK, C.J. 2009. The socio-economic realities of the social work students of the University of South Africa. Social Work/Maatskaplike Werk, 45(3):299-313.

SCOTT, I. 2008. First-year experience as terrain of failure or platform for future development? Critical choices for higher education. Paper presented at the $1^{\text {st }}$ Southern African Conference on the First-year Experience. Stellenbosch, South Africa.

SCOTT, I., YELD, N. \& HENDRY, J. 2007. A case of improving teaching and learning in South African higher education. Higher Education Monitor no. 6. Pretoria: Council on 
Higher Education. [Online] Available: http:/www.che.ac.za/documents/d00155/ [Accessed: 02/09/2009]

SUTHERLAND, P. 1998. Experiential learning and constructivism: potential for a mutually beneficial synthesis. In: SUTHERLAND, P. (ed) Adult learning: a reader. London: Kogan Page.

TSHIWULA, L. 2007. Resilience in a higher education institution. Inaugural lecture. University of the Western Cape, South Africa.

VAN BREDA, A. D. \& NEFDT, B. 2009. A critical evaluation of the use of Blackboard to facilitate the development of academic competencies among first-year students. Paper presented at the Blackboard Africa User Conference. Bloemfontein, South Africa.

WICHITA STATE UNIVERSITY. (n.d.). Basic academic competencies. [Online] Available: http://advising.witchita.edu/lasac/pubs/aah/basicomp.htm. [Accessed: 07/04/2009]

WOLPE, H., BADAT, S. \& BARENDS, Z. 1993. The post-secondary education system: beyond the equality vs. development impasse and towards policy formulation for equality and development. Cape Town: Education Policy Unit, University of the Western Cape.

Prof Kathleen Collins, Department of Social Work, University of the Western Cape; Dr Adrian van Breda, Department of Social Work, University of Johannesburg, South Africa. 